\title{
Helminth community structure study on urban and forest blackbird (Turdus merula L.) populations in relation to seasonal bird migration on the south Baltic Sea coast (NW Poland)
}

\author{
I. RZĄD ${ }^{1}$, J. SITKO ${ }^{2}$, R. SAŁAMATIN ${ }^{3,4}$, D. WYSOCKI ${ }^{5}$
}

\begin{abstract}
${ }^{1}$ Department of Ecology and Environmental Protection, University of Szczecin, Wąska 13, 75-015 Szczecin, Poland, E-mail: Izabela.rzad@univ.szczecin.pl; ${ }^{2}$ Comenius Museum, Moravian Ornithological Station, Horní nám. 7, 75002 Přerov, Czech Republic, E-mail: j.sitko@email.cz; ${ }^{3}$ Department of General Biology and Parasitology, Medical University of Warsaw, T. Chałubińskiego 5, 02-004 Warsaw, Poland, E-mail: ruslan.salamatin@wum.edu.pl; ${ }^{4}$ Department of Medical Parasitology, National Institute of Public Health - National Institute of Hygiene, Chocimska 24, 00-791 Warsaw, Poland; ${ }^{5}$ Department of Anatomy and Vertebrate Zoology, University of Szczecin, Wąska 13, 75-015 Szczecin, Poland, E-mail: darekw@univ.szczecin.pl
\end{abstract}

\begin{abstract}
Summary
The aim of the study was to compare helminth community structure of urban and forest blackbird populations. 24 helminth species in 98 blackbirds were found. Higher species richness was noted in the forest population of the blackbird (23 species) in comparison to the urban population (14 species). The response of the helminth fauna to a synanthropic habitat, contrary to a natural habitat, consists in a significant reduction in most parasitological parameters. Higher species richness has been noted in spring (17 species) than in autumn (14 species). Urban habitat, in contrast to the forest, may cause changes in the abundance of helminth communities in male and female blackbirds. The helminth fauna of nestlings, in spite of low species richness is characterized by a higher prevalence and intensity of infection in comparison to blackbirds feeding on their own. Helminth fauna of the blackbird seems to be a good indicator of environmental quality.
\end{abstract}

Key words: Turdus merula; helminths; urban; forest; migrations

\section{Introduction}

The helminth fauna of the blackbird (Turdus merula Linnaeus 1758) is well known both in Poland (Machalska, 1974, 1978, 1980a, 1981; Okulewicz A., 1979a, b, c, 1981; Okulewicz J., 1982, 1992, 1993; Machalska \& Okulewicz A., 1984; Okulewicz A. et al., 2007; Okulewicz A. et al., 2010) and in other countries (Ryšavý, 1955, 1958; Ryšavý \& Baruš, 1964; Binder, 1971; Hanak \& Vojtek, 1973; Schmidt, 1975; Bogdarenko \& Galina, 1978; Iskova, 1979; Iskova et al., 1995; Salamatin, 2000; Misof, 2005, Sitko et $a l ., 2006)$. The role of habitat in determining the structure of parasite communities has been stressed i.a. by Bush
(1990). Anthropogenic factors, contributing to a distortion of the natural ecosystem influence parasitic organisms as well as free-living ones. They may cause excessive development of populations of some organisms and oust others which are not adjusted well enough (Niewiadomska \& Pojmańska, 2004). Parasites can be an indicator of environmental quality, which has been well documented for aquatic environment by research into parasitic fauna of fish (see e.g. Dzika, 2003). The response of bird parasites to changes in environmental quality has been studied less extensively. Several studies have been devoted to the effect of bird synanthropization on species richness and diversity of their helminths (Rutkowska, 1973; Okulewicz A., 1979a, b; Sitko \& Zaleśny, 2014). A comparative study on nematode fauna of blackbirds in urban and forest habitats was conducted by Okulewicz A. (1979a, b). Furthermore, thanks to the studies conducted by Machalska $(1974,1978$, 1980a, b, 1981) and Machalska and Okulewicz A. (1984), digeneans, nematodes and acantocephalans, of migrating blackbirds are well known. Finally, the effect of blackbird urbanization on its helminth fauna has been proved by a comparative study conducted in the eastern part of the Czech Republic (Sitko \& Zaleśny, 2014). However, studies devoted to urban blackbird populations are rather few and we still do not have sufficient knowledge about the helminths of birds which show a tendency for synanthropization. The blackbird is a very good object of study because it forms two types of populations: the forest population, living in a natural habitat, and the synanthropic population, which has been associated with an urban habitat for a long time. Urban and forest blackbird populations can differ with respect to biological and ethological characteristics, including the extent of undertaking seasonal migrations, diet, ways of obtaining food and the diversity of 
feeding grounds. Already in the 1970s it was noted that most forest blackbirds (ca. two thirds of the total population) migrated for winter, whereas urban blackbirds led a sedentary lifestyle, since their urge to migrate had disappeared (Graczyk, 1961).

As noted by Bush (1990), a seasonal character of environmental quality is one of the factors which can play an important role in helminth distribution. It is especially important in the case of migratory birds, as spring and autumn migrations provide opportunities for transfer of numerous parasite species (Niewiadomska \& Pojmańska, 2004). For example, the following trematode species have been reported during migration time of birds: Brachylaima arquata in birds belonging to the genus Turdus: (Machalska, 1980a), Mihajlovia migrata in Turdus philomelos; Cyclocoelum polonicum and Laterotrema vexans in T. merula and T. philomelos (Sulgostowska \& Czaplińska, 1987); the cestode species: Emberizotaenia raymondi (syn. Ptilotolepis philomelae J. Okulewicz, 1991) in T. philomelos: (Okulewicz J., 1991), and acantocephalans: Corynosoma pyriforme and Sphaerostris lancea in $T$. merula: (Machalska, 1981). Trematode species Mossesia sittae and Mossesia microsome noted in the Turdidae of Lower Silesia had formerly been noted in the Far East (Okulewicz J., 1993). Typically "southern" species (Dogiel, 1962) have been identified among trematodes of birds in the Czech Republic, accidentally introduced from tropical regions, e.g. Brachydistomum olssoni brought by the common swift Apus apus (Sitko et al., 2006) and Morishitium elongatum, Mossesia microsome, Psilotornus contortus, Euamphimerus pancreaticus, Mihajlovia migrata brought by T. merula (Sitko \& Zaleśny, 2014).

Studies on bird migration conducted on the Polish Baltic Sea coast and results of the analyses of information about returning ringed birds indicate that two migration streams of the blackbird run through the Polish coast. One runs towards the Atlantic coast of Europe and the other towards the Czech Republic and beyond, to the western and central Mediterranean Sea shores. Those two streams divide blackbirds into different "migrant" populations (J. Chruściel, unpublished data). Furthermore, Czech blackbirds presumably overwinter in Italy, while most blackbirds flying over the Polish coastal region presumably overwinter in France. Information about seasonal migration routes is necessary for parasitologists to analyze the helminth fauna structure of migratory birds.

Age and sex of the host are factors frequently determining the structure of a parasite community (e.g. Bush, 1990; Poulin, 1996; Zuk \& McKean, 1996; Margolis \& Cone, 1997; Schalk \& Forbes, 1997; Isomursu et al., 2006; Robinson et al., 2008; Calegaro-Marques \& Amato, 2010). The role of testosterone has also been stressed in literature (Folstad \& Karter, 1992, but see Roberts et al., 2004). Blackbirds are the only thrush species showing sexual dimorphism, but body size and weight of males and females are similar (Wysocki, 2002). Only females build nests but otherwise both sexes lead a similar lifestyle. No differences have been noted in their diet, either (Glutz von Blotzheim et al., 1982).
The aim of the study was to gain insight into the relation between the structure of the helminth fauna on the one hand and the habitat and seasonal migration of the blackbird from the southern coast of the Baltic Sea on the other. We assumed that in the studied geographical region the component community of helminths in the forest population of the blackbird would be richer than in the synanthropic population. Probably there would also be a significant difference between spring and autumn in the forest population of the blackbird. We also assumed that the helminth fauna of males and females would not differ significantly and that the helminth fauna of nestlings would be much less diversified than that of the blackbirds, feeding on their own. The applied method of collecting helminths took into account the principles of environmental protection. In many European countries the blackbird is a game bird but in Poland it is a protected species. However, it frequently falls prey to predators such as cats, martens and corvids (Bauer et al., 2005). According to a study conducted in the Czech Republic, helminths were a probable cause of death of 41 passerines, including 9 blackbirds $T$. merula (Okulewicz A. \& Sitko, 2012). As noted by Hromada et al. (2000) many museums continue to acquire material by collecting dead birds which died of "natural" causes. Most ringing teams, throughout their work, also find birds that die of exhaustion, and most of us find dead birds from time to time, as well (Hromada et al., 2000). In this study we show that material collected from dead birds is useful and can bring measurable benefits for science. Results of the study will expand available knowledge and contribute to forming general ideas about the reduction of the helminth fauna richness of the blackbird in synanthropic habitat. They will also show that the structure of helminth community of the blackbird seems to be an indicator of environmental quality in urban areas.

\section{Material and methods}

In the years $2006-2012,98$ blackbirds from the southern coast of the Baltic Sea in north-western Poland were studied (Table 1). The specimens represented forest blackbird populations from the following sites: Wisełka (53 $57^{\prime}$ $\mathrm{N}, 14^{\circ} 34^{\prime}$ E) Goleniów $\left(53^{\circ} 33^{\prime} \mathrm{N}, 14^{\circ} 49^{\prime} \mathrm{E}\right)$, Kopań $\left(54^{\circ} 27^{\prime} \mathrm{N}, 1^{\circ} 25^{\prime} \mathrm{E}\right)$, Wicie $\left(54^{\circ} 30^{\prime} \mathrm{N}, 1^{\circ} 28^{\prime} \mathrm{E}\right)$, Choczewo (54 $\left.44 \mathrm{~N}, 17^{\circ} 53^{\prime} \mathrm{E}\right)$, Hel (Kuźnica) $\left(54^{\circ} 44^{\prime} \mathrm{N}\right.$, $\left.18^{\circ} 34^{\prime} \mathrm{E}\right)$, Pobierowo ( $\left.54^{\circ} 3^{\prime} \mathrm{N}, 14^{\circ} 55^{\prime} \mathrm{E}\right)$ and the urban blackbird population from the city of Szczecin $\left(53^{\circ} 26^{\prime} \mathrm{N}\right.$, $\left.14^{\circ} 32^{\prime} \mathrm{E}\right)$. Blackbird specimens from forest populations were collected mainly in spring and in autumn, while specimens of urban blackbirds were collected mainly in spring and in summer (Table 1). The sex of blackbirds feeding on their own was identified at necropsy. There were $17(53 \%)$ males and $12(38 \%)$ females and $3(9 \%)$ non sexed individuals among the collected urban blackbirds, and $21(45 \%)$ males and 18 (38\%) females and $8(17 \%)$ non sexed individuals among the collected forest blackbirds. Helminths were preserved in $70-75 \%$ ethanol. Permanent microscope slides stained with alum carmine and 
acetocarmine were prepared from trematodes and cestodes. Cestode scolices were cleared in Fora fluid. Nematodes and acantocephalans were cleared in lactic acid.

Qualitative and quantitative structure of helminth community of forest and urban blackbird populations was determined at the level of a component community and infracommunities. Structure analysis was conducted according to the terminology proposed by Bush et al. (1997). Basic parasitological parameters were determined, such as: prevalence $(P)$, mean intensity of infection $(M I)$ and range (min - max) (Bush et al., 1997). Community richness was determined on the basis of the number of helminth species. A relationship between the helminth community structure and blackbird habitat was studied by comparing a group of urban blackbirds with a group of forest blackbirds during spring and summer (Table 1). A relationship between the helminth community structure and seasonal host migration was studied by comparing the helminth community structure of forest blackbirds in spring and in autumn. A relationship between the helminth community structure and the sex of blackbirds was studied by comparing groups of males and females in the urban and the forest habitat. The helminth fauna of nestlings (age 5-14 days) was studied by comparing them with blackbirds feeding on their own in the urban habitat (immature, adult and juvenile birds were combined together) (Table 1). Helminth species diversity, expressed by Simpson's diversity index, $1-\mathrm{D}\left(D=\Sigma\left[n_{i}\left(n_{i}\right.\right.\right.$ $-1) / N(N-1)]$ ) was determined for the studied group of blackbirds, where $n_{i}$ was a number of individuals of the species $i$ and $N$ was the total number of helminths in a given community (Magurran, 2004). The value of this index ranged between 0 and 1 ; the greater the value of the index, the greater the sample diversity. Furthermore, Berger-Parker's index of dominance was calculated $(d=$ $N_{\max } / N$ ) where $N_{\max }$ was a number of individuals of the most abundant species and $N$ was the total number of individuals, showing the proportion of the most common species in the community or sample, and finally, Jaccard's index of similarity $(J=[c /(a+b+c)] \times 100)$, determining faunistic similarity among communities, where $a$ was the number of species present only in sam-ple $1, b$ was the number of species present only in sample 2 and $c$ was the total number of species present in both samples.

The following set of parameters was compared among various blackbird groups:

- The prevalence of helminths representing respective systematic groups (Digenea, Cestoda, Nematoda, Acanto- cephala) expressed by the percentage share of infected hosts;

- The number of helminth species per each examined host and the number of helminth species representing respective systematic groups (Digenea, Cestoda, Nematoda, Acantocephala) per each examined host (mean $\pm S D$ );

- The number of parasites expressed by the number of helminths per each examined host, including the number of helminths representing respective systematic groups (Digenea, Cestoda, Nematoda, Acantocephala) (mean $\pm S D$ );

- The number of parasites belonging to species characterized by the highest prevalence per each examined host (mean $\pm S D$ ).

As distributions of variables deviated from normal distribution, values of parameters were transformed by logarithming. After the transformation, the distribution of the studied variables acquired the characteristics of a normal distribution (Dytham, 2011). The significance of differences was determined using a parametric test $(t)$; samples were compared in pairs. Results feature parameter values which show significant differences: $p \leq 0.05, p \leq 0.01$ and $p \leq 0.001$.

In drawing up the checklist of helminths of the blackbird in Poland original works were used, as well as keys (Gibson et al., eds., 2002, Jones et al., eds. 2005), catalogues of parasitic fauna of Poland (Sulgostowska \& Czaplińska, 1987; Czapliński et al., 1992; Okulewicz, 1997; Sulgostowska, 1997), the internet database Fauna Europaea (de Jong, 2013), the monograph by Pojmańska et al. (2007), and finally, also the results of the authors' own research (see Table 6). The compiled checklist of helminths includes information on synonyms featured in literature and main references. Data from the checklist has been used for discussion on helminth species typically found in different migratory populations of the blackbird: the "southern" population whose seasonal migration route runs through southern Poland (S Poland) and the Czech Republic, and the "northern" population migrating through northern Poland (N Poland).

\section{Results}

Twenty-four helminth species were found (9 Digenea, 8 Cestoda, 5 Nematoda and 2 Acantocephala). Species richness of the helminth fauna of forest blackbirds was higher than species richness of urban blackbirds (Table 2). In the forest blackbird population 23 helminth species were noted

Table 1. Material. Number of examined blackbirds in the urban and the forest habitat

\begin{tabular}{lcccc}
\hline & \multicolumn{2}{c}{ Urban habitat } & Forest habitat & Total \\
\cline { 2 - 4 } Phenological season & Nestlings & $\begin{array}{c}\text { Blackbirds feeding on } \\
\text { their own }\end{array}$ & $\begin{array}{c}\text { Blackbirds feeding on } \\
\text { their own }\end{array}$ & \\
\hline Spring (III - V) & 4 & 21 & 18 & 43 \\
Summer (VI - VIII) & 15 & 4 & 2 & 21 \\
Autumn (IX - XI) & 0 & 1 & 24 & 25 \\
Winter (XII - II) & 0 & 6 & 3 & 9 \\
Total & $\mathbf{1 9}$ & $\mathbf{3 2}$ & $\mathbf{4 7}$ & $\mathbf{9 8}$ \\
\hline
\end{tabular}




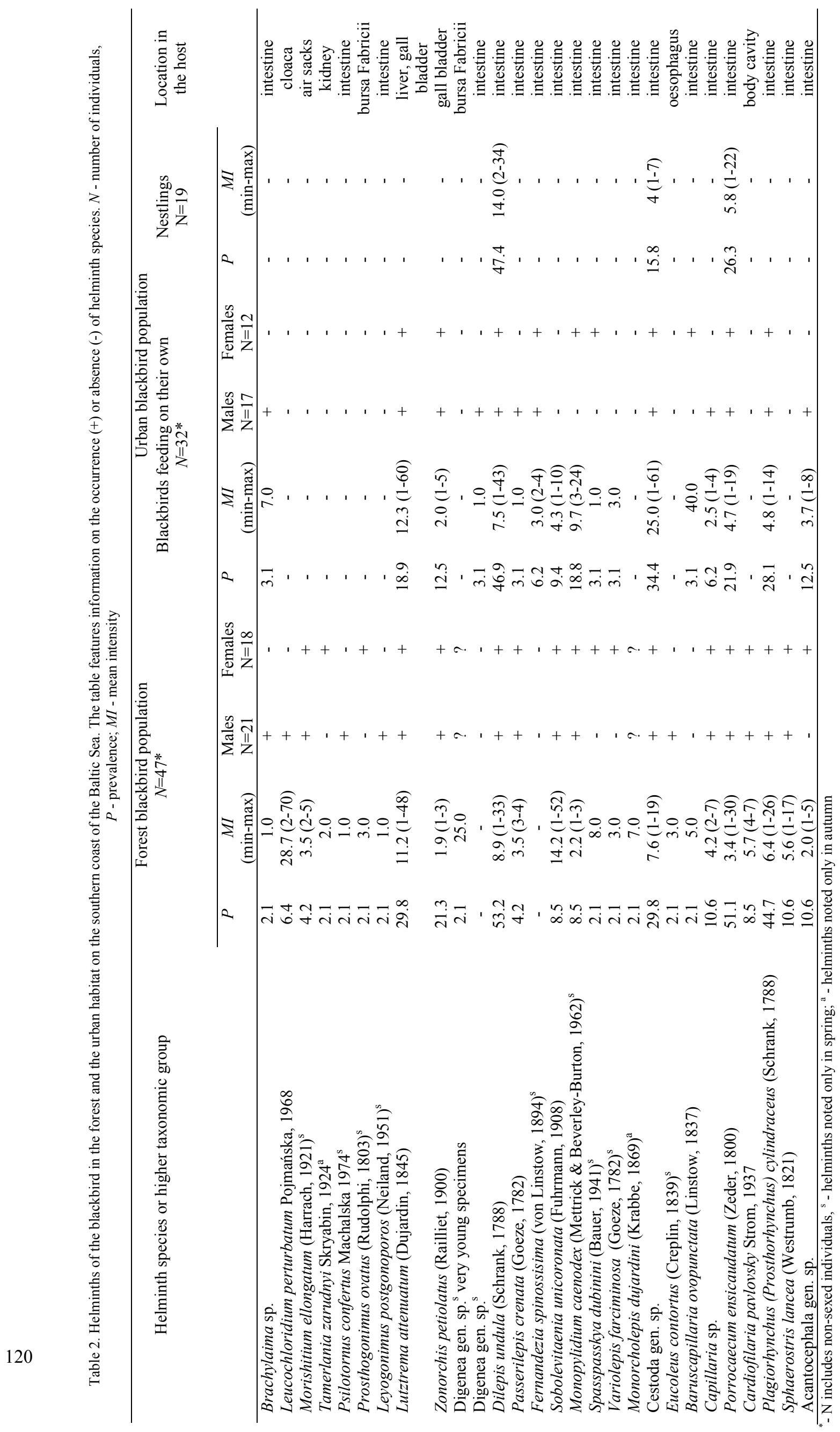


Table 3. A comparison of infection with helminths between blackbirds in the forest and the urban habitat, in spring and in summer. Mean values $($ mean $\pm S D)$ refer to each examined host. Dominant helminth species are given next to the values of Berger-Parker's index

\begin{tabular}{|c|c|c|c|c|}
\hline \multicolumn{2}{|c|}{ Set of parameters } & $\begin{array}{l}\text { Forest habitat } \\
(\mathrm{N}=20)\end{array}$ & $\begin{array}{l}\text { Urban habitat } \\
(\mathrm{N}=25)\end{array}$ & $p$ \\
\hline \multirow[t]{5}{*}{ Prevalence of helminths: } & Total prevalence & $100 \%$ & $84 \%$ & $0.0173 *$ \\
\hline & Digenea & $65 \%$ & $28 \%$ & $0.0055 * *$ \\
\hline & Cestoda & $90 \%$ & $76 \%$ & 0.1021 \\
\hline & Nematoda & $65 \%$ & $40 \%$ & $0.0457 *$ \\
\hline & Acantocephala & $90 \%$ & $28 \%$ & $<0.0001 * * *$ \\
\hline \multirow[t]{5}{*}{ Number of species: } & Total number of helminths & $4.05 \pm 1.53$ & $2.12 \pm 1.34$ & $<0.0001 * * *$ \\
\hline & Digenea & $1.00 \pm 0.95$ & $0.32 \pm 0.55$ & $0.0032 * *$ \\
\hline & Cestoda & $1.30 \pm 0.78$ & $1.12 \pm 0.82$ & 0.1576 \\
\hline & Nematoda & $0.80 \pm 0.68$ & $0.40 \pm 0.49$ & $0.0225 *$ \\
\hline & Acantocephala & $0.95 \pm 0.38$ & $0.28 \pm 0.45$ & $<0.0001 * * *$ \\
\hline \multirow{5}{*}{$\begin{array}{l}\text { Number of individuals: } \\
\text { (groups) }\end{array}$} & Total number of helminths & $35.45 \pm 31.57$ & $19.76 \pm 22.14$ & $0.0066 * *$ \\
\hline & Digenea & $10.10 \pm 18.66$ & $3.16 \pm 11.37$ & $0.0083 * *$ \\
\hline & Cestoda & $14.40 \pm 13.90$ & $11.60 \pm 17.38$ & 0.0640 \\
\hline & Nematoda & $3.90 \pm 6.94$ & $3.12 \pm 8.43$ & 0.0944 \\
\hline & Acantocephala & $7.05 \pm 7.20$ & $1.88 \pm 4.07$ & $<0.0001 * * *$ \\
\hline \multirow{4}{*}{$\begin{array}{l}\text { Number of individuals: } \\
\text { (species) }\end{array}$} & L. attenuatum & $4.0 \pm 10.54$ & $2.84 \pm 11.76$ & 0.1193 \\
\hline & D. undula & $8.70 \pm 8.50$ & $4.28 \pm 8.92$ & $0.0079 * *$ \\
\hline & P. ensicaudatum & $2.65 \pm 6.53$ & $1.32 \pm 3.78$ & 0.1180 \\
\hline & P. cylindraceus & $6.25 \pm 7.11$ & $1.32 \pm 3.44$ & $<0.0001 * * *$ \\
\hline Simpson's index $(1-D)$ & & 0.870 & 0.855 & \\
\hline \multirow[t]{2}{*}{ Berger-Parker's index } & & 0.247 & 0.216 & \\
\hline & & D. undula & D. undula & \\
\hline
\end{tabular}

and 14 helminth species were noted in the urban blackbird population. The highest difference was noted in the case of the Digenea. Species with the highest prevalence included D. undula and Plagiorhynchus cylindraceus in both the forest and the urban blackbird population, and Lutztrema attenuatum and Porrocaecum ensicaudatum in the forest population.
Higher values of parasitological parameters were noted in forest blackbirds in comparison to urban blackbirds (Table 3). Statistically significant differences were discovered in the species richness of helminths, in the prevalence of helminths, including digeneans, nematodes and acantocephalans and in the number of helminths including the number of the digeneans and acantocephalans of forest and

Table 4. A comparison of infection with helminths between the spring and autumn in the forest blackbird population. Mean values (mean $\pm S D$ ) refer to each examined host. Dominant helminth species are given next to the values of Berger-Parker's index

\begin{tabular}{|c|c|c|c|c|}
\hline \multicolumn{2}{|c|}{ Set of parameters } & Spring $(N=18)$ & Autumn $(N=24)$ & $p$ \\
\hline \multirow{5}{*}{$\begin{array}{l}\text { Prevalence of } \\
\text { helminths: }\end{array}$} & Total prevalence & $100 \%$ & $92 \%$ & 0.0742 \\
\hline & Digenea & $67 \%$ & $38 \%$ & $0.0282 *$ \\
\hline & Cestoda & $89 \%$ & $67 \%$ & $0.0374 *$ \\
\hline & Nematoda & $67 \%$ & $58 \%$ & 0.2891 \\
\hline & Acantocephala & $94 \%$ & $33 \%$ & $<0.0001 * * *$ \\
\hline \multirow{5}{*}{ Number of species: } & Total number of helminths & $3.95 \pm 1.00$ & $2.33 \pm 1.70$ & $0.0002 * * *$ \\
\hline & Digenea & $1.06 \pm 0.97$ & $0.50 \pm 0.76$ & $0.0206^{*}$ \\
\hline & Cestoda & $1.33 \pm 0.82$ & $0.79 \pm 0.64$ & $0.0121 *$ \\
\hline & Nematoda & $0.78 \pm 0.63$ & $0.71 \pm 0.68$ & 0.3530 \\
\hline & Acantocephala & $1.0 \pm 0.33$ & $0.33 \pm 0.47$ & $<0.0001 * * *$ \\
\hline \multirow{5}{*}{$\begin{array}{l}\text { Number of idividuals: } \\
\text { (groups) }\end{array}$} & Total number of helminths & $37.33 \pm 32.52$ & $10.38 \pm 13.59$ & $<0.0001^{* * *}$ \\
\hline & Digenea & $11.11 \pm 19.41$ & $3.54 \pm 9.34$ & $0.0206^{*}$ \\
\hline & Cestoda & $14.61 \pm 14.42$ & $3.75 \pm 5.64$ & $0.0007 * * *$ \\
\hline & Nematoda & $3.89 \pm 7.19$ & $1.75 \pm 2.44$ & 0.1185 \\
\hline & Acantocephala & $7.72 \pm 7.28$ & $1.33 \pm 3.52$ & $<0.0001 * * *$ \\
\hline \multirow{4}{*}{$\begin{array}{l}\text { Number of idividuals: } \\
\text { (species) }\end{array}$} & L. attenuatum & $4.44 \pm 11.02$ & $3.21 \pm 9.24$ & 0.2114 \\
\hline & D. undula & $8.28 \pm 8.50$ & $1.96 \pm 4.43$ & $0.0007 * * *$ \\
\hline & P. ensicaudatum & $2.89 \pm 6.84$ & $0.88 \pm 0.93$ & 0.1720 \\
\hline & P. cylindraceus & $6.94 \pm 7.16$ & $0.42 \pm 1.08$ & $<0.0001 * * *$ \\
\hline \multirow{3}{*}{\multicolumn{2}{|c|}{$\begin{array}{l}\text { Simpson's index }(1-D) \\
\text { Berger-Parker's index }\end{array}$}} & 0.873 & 0.829 & \\
\hline & & 0.223 & 0.319 & \\
\hline & & D. undula & L. attenuattum & \\
\hline
\end{tabular}

Significance levels: ${ }^{*}-p \leq 0.05,{ }^{* *}-p \leq 0.01,{ }^{* * *}-p \leq 0.001$ 
Table 5. A comparison of infection with helminths between nestlings and blackbirds feeding on their own in the urban habitat

\begin{tabular}{|c|c|c|c|c|}
\hline \multicolumn{2}{|c|}{ Set of parameters } & \multirow{2}{*}{$\begin{array}{c}\text { Nestlings } \\
(\mathrm{N}=19) \\
63 \%\end{array}$} & \multirow{2}{*}{$\begin{array}{c}\text { Blackbirds feeding } \\
\text { on their own }(\mathrm{N}=32) \\
84 \%\end{array}$} & \multirow[t]{2}{*}{$p$} \\
\hline Prevalence of helminths: & Total prevalence & & & \\
\hline & Digenea & $0 \%$ & $28 \%$ & $0.0004 * * *$ \\
\hline & Cestoda & $63 \%$ & $78 \%$ & 0.1333 \\
\hline & Nematoda & $26 \%$ & $31 \%$ & 0.3511 \\
\hline & Acantocephala & $0 \%$ & $34 \%$ & $<0.0001 * * *$ \\
\hline \multirow[t]{5}{*}{ Number of species: } & Total number of helminths & $0.89 \pm 0.79$ & $2.09 \pm 1.35$ & $0.0008 * * *$ \\
\hline & Digenea & $0.00 \pm 0.00$ & $0.38 \pm 0.66$ & $0.0008 * * *$ \\
\hline & Cestoda & $0.63 \pm 0.48$ & $1.06 \pm 0.75$ & $0.0311^{*}$ \\
\hline & Nematoda & $0.26 \pm 0.44$ & $0.31 \pm 0.45$ & 0.3987 \\
\hline & Acantocephala & $0.00 \pm 0.00$ & $0.34 \pm 0.48$ & $<0.0001 * * *$ \\
\hline \multirow{5}{*}{$\begin{array}{l}\text { Number of individuals: } \\
\text { (groups) }\end{array}$} & Total number of helminths & $8.63 \pm 13.32$ & $16.38 \pm 20.65$ & $0.0401^{*}$ \\
\hline & Digenea & $0.00 \pm 0.00$ & $2.81 \pm 10.64$ & $0.0023^{*}$ \\
\hline & Cestoda & $7.11 \pm 9.77$ & $9.31 \pm 15.96$ & 0.4014 \\
\hline & Nematoda & $1.53 \pm 4.91$ & $2.44 \pm 7.56$ & 0.2856 \\
\hline & Acantocephala & $0.00 \pm 0.00$ & $1.81 \pm 3.86$ & $0.0005 * * *$ \\
\hline \multirow{4}{*}{$\begin{array}{l}\text { Number of individuals: } \\
\text { (species) }\end{array}$} & L. attenuatum & $0.00 \pm 0.00$ & $2.31 \pm 10.61$ & $0.0163 *$ \\
\hline & D. undula & $6.63 \pm 9.96$ & $3.50 \pm 8.03$ & 0.1391 \\
\hline & P. ensicaudatum & $1.53 \pm 4.91$ & $1.03 \pm 1.04$ & 0.3746 \\
\hline & P. cylindraceus & $0.00 \pm 0.00$ & $1.34 \pm 3.34$ & $0.0027 * *$ \\
\hline Simpson's index $(1-D)$ & & 0.368 & 0.865 & \\
\hline \multirow[t]{2}{*}{ Berger-Parker's index } & & 0.773 & 0.215 & \\
\hline & & D. undula & D.undula & \\
\hline
\end{tabular}

urban blackbirds. Simpson's diversity index was slightly higher for the forest blackbird population than for the urban blackbird population. Helminth communities of both the forest and the urban population were dominated by $D$. undula. Faunistic similarity expressed by Jaccard's index amounted to $26 \%$.

Higher values of parasitological parameters were noted in spring (Table 4). Seventeen helminth species were found in spring and fourteen were found in autumn. Statistically significant differences were found regarding species richness of helminths, total prevalence of helminths and prevalence and number of individuals representing the Digenea, Cestoda and Acantocephala, including the number of D. undula and Plagiorhynchus cylindraceus. Biodiversity of the helminth community expressed by Simpson's diversity index was higher in spring than in autumn. BergerParker's index of dominance was higher in autumn than in spring and Lutztrema attenuatum was a dominant species. The faunistic similarity between the spring and autumn in the forest population (Jaccard's index) was $22 \%$.

A comparison of helminth community structure of males and females showed that it differed between the urban and the forest population (Table 2). In the forest population no statistically significant differences were discovered between males and females with respect to the analyzed set of parameters. Differences which were the closest to the estimated level of significance referred to the prevalence of cestodes (males: $62 \%$; females: $83 \% ; p=0.064$ ) and the number of $D$. undula - for males: $5.81 \pm 6.07$ (mean $\pm S D$ ) per one examined host; for females: $4.06 \pm 8.55$; $p=$ 0.070 . The faunistic similarity of helminth communities of males and females in the forest population equaled $26 \%$. A comparison of males and females in the urban blackbird population revealed significant statistical differences with respect to the number of helminths per host - males: 10.65 \pm 17.05 (mean $\pm S D$ ) per every examined host; females: $25.33 \pm 23.11 ; p=0.042$, including the number of cestodes (males: $2.88 \pm 3.61$ per every examined host; females: $18.08 \pm 21.75 ; p=0.011)$. Differences which were the closest to the estimated level of significance referred to the prevalence of cestodes (males: $71 \%$; females: $92 \% ; p=$ 0.066 ) and the number of cestodes species (males: $0.88 \pm$ 0.68 ; females: $1.25 \pm 0.60 ; p=0.059$ ) and also the number of nematodes (males: $0.47 \pm 0.98$ per every examined host; females: $5.50 \pm 11.62 ; p=0.061)$. The faunistic similarity of helminth communities of males and females in the urban population equaled $23 \%$.

Prevalence of helminths in nestlings in the urban blackbird population was equal to $63 \%$ while in the group of blackbirds feeding on their own $84 \%(p=0.0518)$. Helminths found in nestlings included only 2 species of helminths (Table 2). In nestlings there were not found any Digenea or Acanthocephala. A comparison of the helminth community structure of nestlings and blackbirds feeding on their own revealed statistically significant differences with respect to a few parameters (Table 5). Simpson's index was lower in nestlings than in blackbirds feeding on their own and Berger - Parker's index was higher. The faunistic similarity between nestlings and females was higher than the faunistic similarity between nestlings and males, Jaccard's index: $19 \%$ and $16 \%$ respectively. 


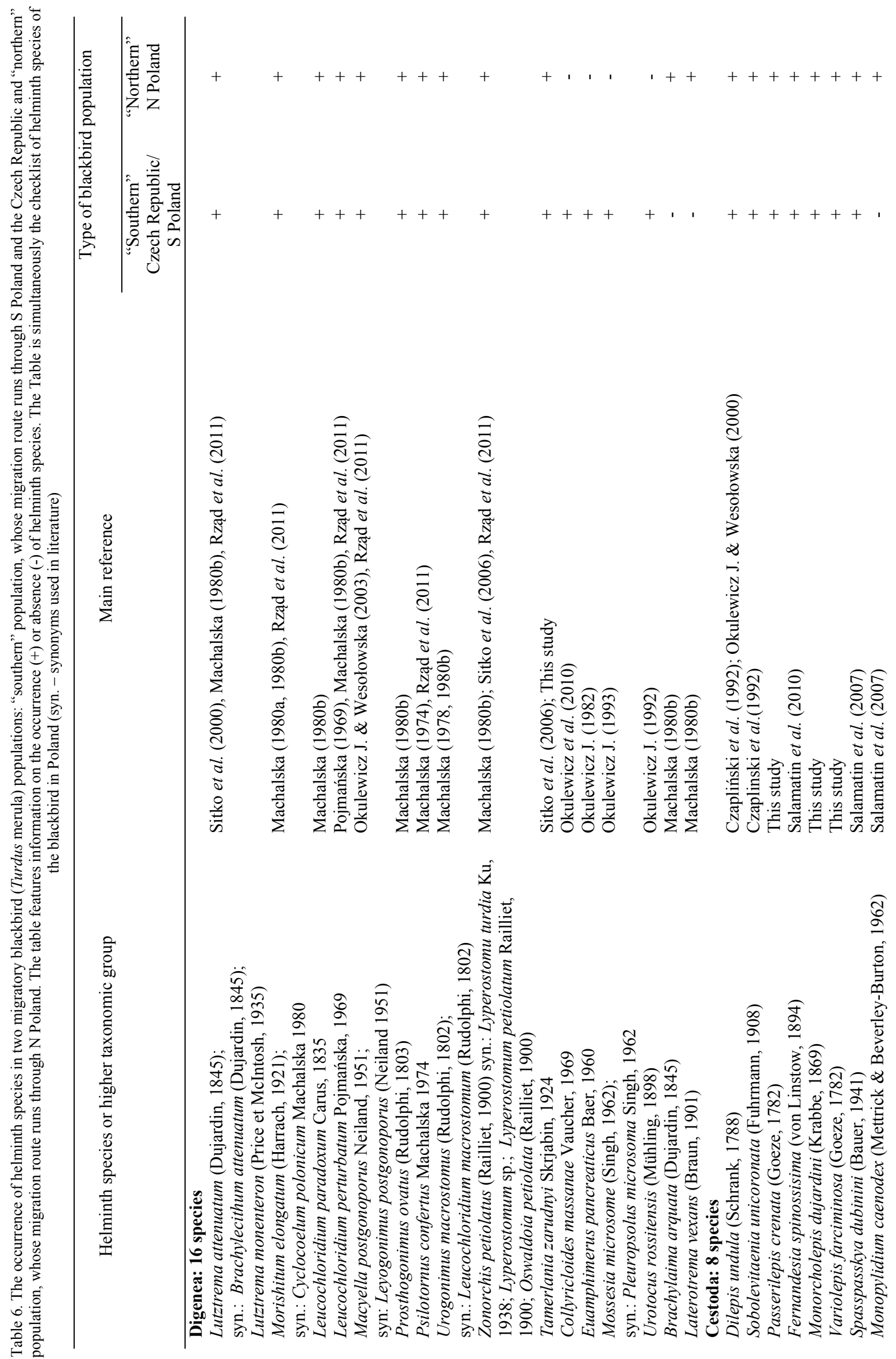



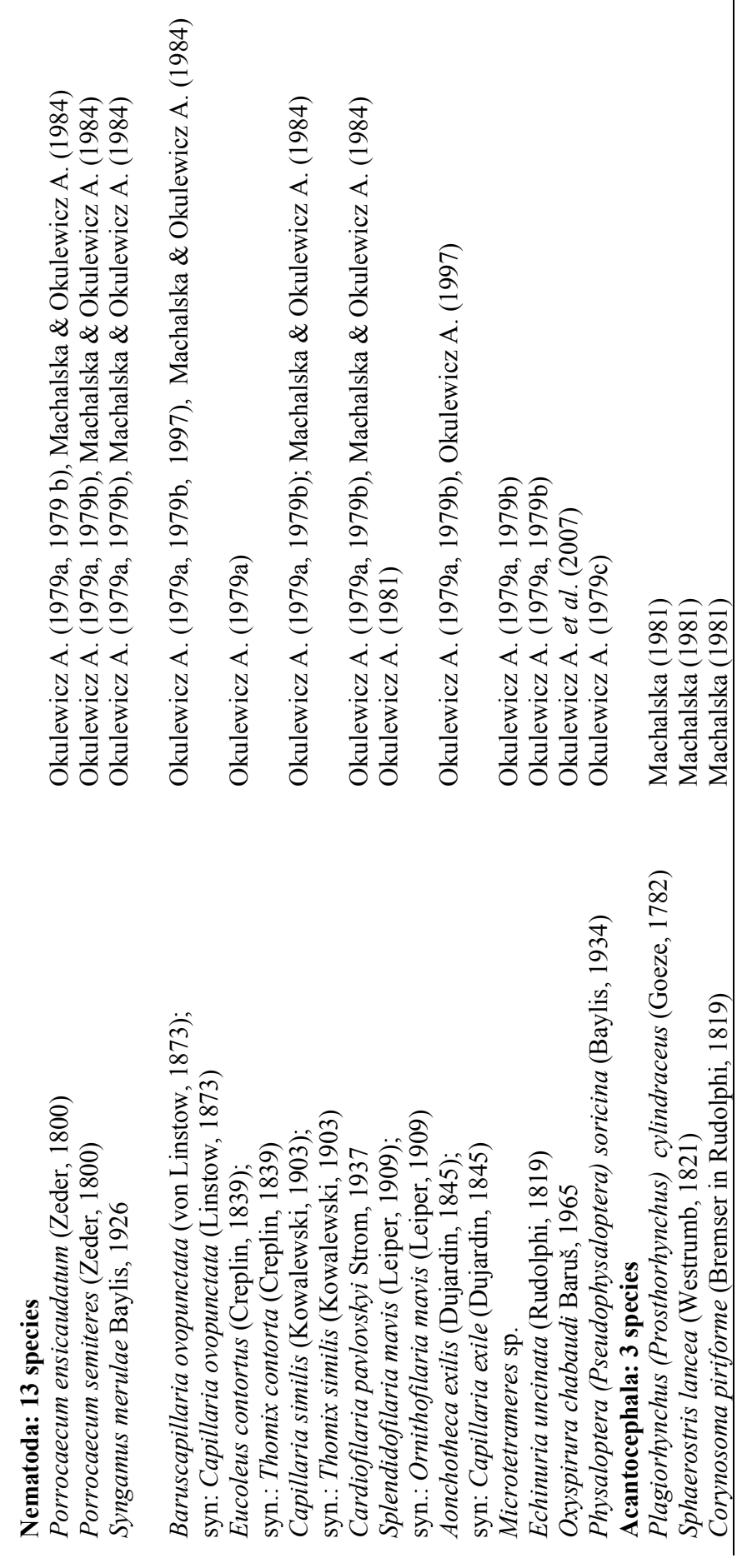


\section{Discussion}

Presented study results confirm that the helminth fauna structure is related to factors characterizing the natural and the synanthropic habitat. These results coincide with results obtained by Sitko and Zaleśny (2014) who studied the helminth fauna of blackbirds in the eastern part of the Czech Republic. The authors showed that urbanization led to a significant reduction in the helminth fauna of the blackbird since the hosts adjusted themselves to the synanthropic habitat (Sitko \& Zaleśny, 2014). An identical trend noticed in studies on various blackbird populations of the Baltic Sea Coast and the Czech Republic justifies a generalization that urbanization leads to a reduction in the species diversity of the helminth fauna of a bird species living in a synanthropic habitat in comparison to a bird species living in its natural forest habitat (Sitko \& Zaleśny, 2014). A similar tendency showing a difference between the intensity of infection in forest and city habitats was revealed by studies on blood parasites of the blackbird (Hatchwell et al., 2000; Bentz et al., 2006; Geue \& Partecke, 2008). The helminth fauna of the blackbird is wellknown in Poland (Table 6), and it can provide a good model for studying the connection between the helminth fauna structure of an avian host and the host's adjustment to life in an urban habitat when more extensive research is conducted in the future. The checklist of helminths of the blackbird in Poland, featuring 40 species (16 Digenea, 8 Cestoda, 13 Nematoda and 3 Acantocephala), systematizes available knowledge on the helminth fauna of this host (Table 6).

A difference between helminth communities of the forest and urban habitat is clearly characterized by species richness expressed by the number of helminth species. Ten helminth species were found only in the forest habitat and one species was found only in the urban habitat (Table 2). Another 13 species were common for both the forest and the urban blackbird population. Apart from the above striking difference, helminth communities of the forest and the urban blackbird population were characterized by a certain similarity. It was reflected by the presence of species with higher infection parameters than in the case of the remaining helminths. In both populations, such species included: Lutztrema attenuatum, Dilepis undula, Porrocaecum ensicaudatum and Plagiorhynchus cylindraceus (Table 2). The same tendency could be seen in study results obtained by Sitko and Zaleśny (2014). The above helminths are typical for and common among birds of the genus Turdus. D. undula occurs all over Poland and its presence has been confirmed in many bird species, i.a. Corvus spp., Pica pica, T. merula and T. philomelos (Pojmańska et al., 2007). Porrocaecum ensicaudatum is a cosmopolitan species, characteristic for Passeriformes. It has been encountered in many bird species in Poland, i. a. those belonging to the genera Corvus and Turdus (Okulewicz A., 1997). As for Plagiorhynchus cylindraceus, in Poland it has been found in birds of the genera Corvus and Turdus (Sulgostowska, 1997). The habitat of the host plays an important role in forming the structure of helminth community of the blackbird. The prevalence and species richness were higher in all helminth groups in the forest habitat than in the urban habitat. This phenomenon can be explained by a probably lower availability of intermediary hosts in urban areas and different dietary habits of blackbirds in the forest and the urban areas: in the latter blackbirds frequently feed on human food waste having no access to dietary components available to their forest counterparts (Sitko \& Zaleśny, 2014). Those differences are especially noticeable in the case of the digeneans and acantocephalans. The above tendency was noted both in our study and in the study by Sitko and Zaleśny (2014). The number of nematode species per each examined host and the prevalence of nematodes differed between the studied habitats and the differences were statistically significant (Table 3 ). A similar tendency was noted in the study by Okulewicz A. (1979b). Helminth communities of both the urban and the forest blackbird population are strongly dominated by nematodes. Leucochloridium perturbatum is a dominant species in forest blackbirds from the eastern part of the Czech Republic, and D. undula is a dominant species in forest blackbirds in that region (Sitko \& Zaleśny 2014). Leucochloridium perturbatum is a frequent parasite of passerines and waders in the Holarctic Region and in North Africa (Sitko at al., 2006). The difference between the forest blackbird population in Poland and in Czech Republic is interesting and is probably due to a difference in the intermediary host density, i.e. snails of the genus Succinea (Pojmańska, 1969). Similarly to our study, Sitko and Zaleśny (2014) noted high parameters of infection with $D$. undula in both habitat types. Study results suggest that the structure of the component helminth community of the blackbird may find application in future studies focusing on the evaluation of the quality of urban ecosystems to find out how much of a natural character they have retained and to what extent they have been degraded due to urbanization. The response of the helminth fauna to environmental changes facilitates the evaluation of changes taking place in the urban habitat in comparison to the forest habitat, the latter being the natural habitat of the blackbird.

The phenological season and the seasonal migration of blackbirds connected with it play a crucial role in forming the helminth fauna structure in the blackbird. This is reflected by the occurrence of some species only in spring or only in autumn (Table 2). A higher species diversity in spring than in autumn is caused, among other things, by the fact that birds return from the regions where they overwintered bringing parasites which they acquired there. Seasonal bird migrations provide an opportunity for transfer of many parasite species, therefore, when the presence of a parasite is noted in a migratory bird it cannot be certain whether the parasite belongs to native fauna of Poland (Niewiadomska \& Pojmańska, 2004). This can be exemplified by Michajlovia migrata found in T. philomelos in Poland, encountered only twice during the spring migration season (Sulgostowska \& Czaplińska, 1987, Pojmańska 
et al., 2007). This digenean species has recently been found in T. merula in a forest area in the Czech Republic (Sitko \& Zaleśny, 2014). On the basis of study results reported by Dogiel (1962), we were able to select helminth species which infected blackbirds only in the regions where they overwintered ("southern species") and were transferred to breeding grounds during the spring migration. There were two: Morishitium elongatum and Psilotornus confertus. Those digenean species, as well as Leyogonimus postgonoporus (Okulewicz J. \& Wesołowska, 2003) had previously been noted in Poland during the spring migration of turdid species T. merula, T. philomelos and Turdus iliacus (Machalska, 1974, 1980, 1981; Sulgostowska \& Czaplińska 1987). We did not find any of the "southern species" in blackbirds from the urban population (Table 2). The same result was reported by Sitko and Zaleśny (2014). The reasons for the low biodiversity of helminths in spring in the urban habitat in comparison to the forest habitat were probably sedentary lifestyle and the fact that urban blackbirds did not undertake seasonal migration. Spending winter in the city, urban blackbirds were not exposed to an invasion of "alien" helminth species. According to ornithological studies of many years focusing on average migration of the urban blackbird population from Szczecin indicated that ca. $20 \%$ blackbirds migrated for winter, $30 \%$ were nomads (i.e. travelled short distances without going in any specific direction) and $50 \%$ did not migrate for winter at all (Zyskowski \& Wysocki, 2011). Other reasons for a higher species diversity in spring included seasonal changes in the blackbird diet and greater availability of feeding grounds in spring than in summer. Probably, those were the reasons why differences were noted in the number of D. undula and Plagiorhynchus cylindraceus between spring and autumn and the dominance of Lutztrema attenuatum in autumn. According to Okulewicz A. (1979b), one of the reasons why extensive and intense invasions of parasitic helminths persisted was the fact that blackbirds ate large amounts of food before they undertook autumn migration. In autumn, blackbirds largely feed on vegetative food, i.e. berries (Bauer et al., 2005), which is conducive to infection with helminths with simple development cycles. In the present study, no statistically significant differences were found between spring and autumn as for parameters of infection with nematodes (Table 4). Okulewicz A. (1979b) studied the correlation between the nematode fauna and the season and observed seasonal differences comparing summer months to winter months. The author stressed the fact that the seasonal infection dynamics of $T$. merula resulted from changes in the diet of birds. A maximum prevalence and intensity of occurrence of Porrocaecum ensicaudatum in T. merula was noted by the author during summer months, whereas minimum prevalence was noted by her during winter months (Okulewicz A., 1979b). Studies on the occurrence of nematodes of $T$. merula during spring and autumn migrations revealed the presence of 6 nematode species (see Table 5) (Machalska \& Okulewicz A., 1984). Similarly to our study, Porrocaecum ensicaudatum was characterized by the highest prevalence among nematodes (Machalska \& Okulewicz A., 1984).

In future studies, additional information can be obtained by analyzing seasonal migration routes of blackbirds. As it is assumed that blackbirds migrating through northern Poland ("northern" population) and blackbirds migrating through southern Poland in the direction of the Czech Republic ("southern" population) belong to two different migration streams, their helminth fauna structures should be studied separately in future. The analysis of the helminth occurrence in the "southern" and "northern" population allowed for a preliminary selection of species that probably occur in one of those migratory blackbird populations but not the other (Table 6). The trematodes: Collyricloides massanae, Euamphimerus pancreaticus, Mossesia microsome, Urotocus rhositensis and nematodes: Aonchotheca exilis, Microtetrameres sp., Echinuria uncinata, Oxyspirura chabaudi and Physaloptera (Pseudophysaloptera) soricina characterized the "southern" blackbird population. The trematodes: Brachylaima arquata, Laterotrema vexans, cestode species Monopylidium caenodex, and the acantocephalan species Corynosoma piriforme characterized the "northern" blackbird population (Table 6). It can be assumed that the differences were due to different migration routes of the blackbird. An analysis of the relation between the helminth occurrence and blackbird migration routes is rendered difficult by a comparatively low prevalence of the above listed helminths. Therefore, the present study requires a continuation as it indicates perspectives which should be verified by analyzing a larger amount of material.

No statistically significant differences were revealed between males and females in the forest population with respect to the studied parameters. Similar results were obtained by Sitko and Zaleśny (2014) for the blackbird and Calegaro-Marques and Amato (2010) for the rufous-bellied thrush Turdus rufiventris in the metropolitan region of Porto Alegre (Brasil). So far, no insight has been gained into differences concerning the diet of male and female blackbirds (Glutz von Blotzheim et al., 1982). Preliminary results of studies on blackbird behaviour indicate that during the breeding season females feed under the cover of trees much more frequently than males (Wysocki D. unpublished). Males, whose task is to protect their territory, feed mainly on lawns. Howewer, we cannot exclude the possibility that they become infected with certain parasites present in the ground cover under shrubs. Such differences in feeding habits do not exist in the forest, where males and females feed in the same places. In our study, noteworthy differences were discovered between males and females in the urban blackbird population. Contrary to the forest blackbird population, in the urban population the difference between males and females with respect to the infection with cestodes was statistically significant. Furthermore, parameters of infection with nematodes were higher in the case of females than in the case of males. A similar result was obtained by Okulewicz A. (1979b), who noted that the intensity of infection with nematodes of adult females of T. merula in the surroundings of Wrockaw 
was twice as high as in the case of males. Despite the fact that the results coincide they should be confirmed by studying a larger amount of material. If the frequent character of the observed phenomenon will be found its conditionings ought to be studied.

The infection of birds with helminths is tightly connected with the type of consumed food and the manner of feeding, since transmission via food is the most frequent way in which helminths invade the organism of a host. This is connected with differences in parameters of infection between nestlings and blackbirds that feed on their own. The occurrence of cestodes and nematodes was noted in urban nestlings but no digeneans and acantocephalans species were found in this age group. Two helminth species were noted: D. undula and Porrocaecum ensicaudatum. Blackbird nestlings do not look for food on their own but are fed by their parents. Both parents participate in the process (Bauer et al., 2005). Food brought to the nest consists mainly of invertebrates, and intermediary and paratenic hosts of helminths can occur among them. Older blackbirds, able to look for food independently, have a much broader feeding spectrum than nestlings and search for food in diversified habitats. Parameters of nestling infection (D. undula and P. ensicaudatum) were higher than those of blackbirds feeding on their own. A similar result with respect to the high intensity of nestling infection with $P$. ensicaudatum in comparison to adult blackbirds was obtained by Okulewicz A. (1979b). Okulewicz A. (1979b) found representatives of those nematodes in T. merula and T. philomelos nestlings which were only two days old, whereas $55.5 \%$ of nestlings which were $1-5$ days old were infected with $P$. ensicaudatum. The developmental cycle of both $D$. undula, and $P$. ensicaudatum involves the participation of intermediary hosts: earthworms (Oligochaeta). As noted by Okulewicz A. (1979b), the youngest nestlings of $T$. merula are fed mainly with soft, easily digestible food, i.a. earthworms (Korodi Gal, 1967), which explains the high intensity of infection with the above mentioned helminth species.

\section{Acknowledgements}

We would like to thank prof. dr hab. Anna Okulewicz for her assistance with the taxonomic identification of the Capilariidae species. The authors would also like to thank prof. dr hab. Przemysław Busse, the President of the Bird Migration Research Foundation for his assistance with analyzing study results, as well as members and voluntary workers of the Foundation and the "Operation Baltic" for their assistance with collecting bird specimens for parasitological studies.

\section{References}

BAuer, H. G., Bezzel, E., Fiedler, W. (Eds) (2005): Das Kompendium der Vögel Mitteleuropas: alles über Biologie, Gefährdung und Schutz. Nonpasseriformes-Nichtsperlingsvögel. Wiebelsheim: Aula-Verlag, 337 pp.
BINDER, N. (1971): Beiträge zur Morphologie, Invasionsdynamic und Entwicklung der Helminthen der Amsel (Turdus merula L.). Zool. Beitr., 17: 83 - 150

Bentz, S., Rigaud, T., Barroca, M., Martin-Laurent F., Bru D., Moreau, J., FAIVRe, B. (2006): Sensitive measure of prevalence and parasitaemia of haemosporidia from European blackbird (Turdus merula) populations: value of PCR-RFLP and quantitative PCR. Parasitology, 133: 685 - 692. DOI: 10.1017/S0031182006001090

Bogdarenko, F. L., GalinA, Z. A. (1978): [Fauna of trematodes of the thrush family (Turdidae) in Tadzhikistan]. Izvestiya Akademii Nauk Tadzhikskoi SSR. Otdelenie Biologicheskikh Nauk, (3): 15 - 21. (In Russian)

Bush, A. O. (1990): Helminth communities in avian hosts: determinants of a pattern. In: EsCH, E. G., BusH, A. O., AHo, J. M. (Eds) Parasite communities: patterns and processes. London: Chapman \& Hall, pp. 197 - 232

Bush, A. O., Lafferty, K. D., Lotz, J. M., ShostaK, A. W. (1997): Parasitology meets ecology on its terms: Margolis et al. revisited. J. Parasitol., 83(4): 575 - 583.

Calegaro-Marques, C., Amato, S. B. (2010): Parasites as secret files of the trophic interactions of hosts: the case of the rufous-bellied thrush. Revista Mexicana de Biodiversidad, 81(3): $801-811$

Czapliński, B., Sulgostowska, T., CzaplińskA, D. (1992): Catalogus faunae parasiticae poloniae. Parasiti avium. Cestoda. In: Katalog Fauny Pasozytniczej Polski. Volume 4 (2A): 1 - 185. (In Polish)

DZIKA, E. (2003): Parasites (Metazoa) of the common roach Rutilus rutilus (L.) in lakes of the Masurian Lake District as a quality indicator of an aquatic environment. Olsztyn, Poland: Uniwersytet Warmińsko-Mazurski, 81 pp. (In Polish)

DoGIEL, V. A. (1962): [General parasitology]. Leningrad: Izdatelstvo Leningradskogo Universiteta, 464 pp. (In Russian) Dytham, C. (2011): Choosing and Using Statistics; A Biologist's Guide. Chichester: Wiley-Blackwell, 298 pp.

FOLSTAD, I., KARTER, A. J. (1992): Parasites, bright males, and the immunocompetence handicap. Am. Nat. 139: $603-$ 622

Geue, D., Partecke, J. (2008): Reduced parasite infestation in urban Eurasian blackbirds (Turdus merula): a factor favoring urbanization? Can. J. Zool., 86(12): 1419 - 1425. DOI: 10.1139/Z08-129

Gibson, D. I., Jones, A., Bray, R. A. (Eds) (2002): Keys to the Trematoda Volume 1, London: CABI Publishing, $521 \mathrm{pp}$.

Glutz Von Blotzheim, U. N., BAuer, K. M. (1988): Handbuch der Vögel Mitteleuropas. Band 11. Wiesbaden: Aula-Verlag, 1226 pp.

GRACZYK, R. (1961): [Studies on the variability, biology and economic significance of the blackbird (Turdus merula L.)] Ekol. Pol. A, IX, 23: 453 - 485 (In Polish)

HANAK, F., VoJTEK, J. (1973). Zur Kenntis der Helminthenfauna der kleinen Vögel von Mniši Hora (Brno-Bystrc). Folia Scientarium Naturalium Universitatis Purkyniae Brunensis 14, Biologia, 45 - 60 (In Czech with German summary) 
Hatchwell, B. J., Wood, M. J., Anwar, M., Perrins, C. M. (2000): The prevalence and ecology of the haema-tozoan parasites of European blackbirds, Turdus merula. Can. J. Zool., 78: 684 - 687. DOI: 10.1139/z99-228

Hromada, M., DudiŇÁK, V., Yosef, R. (2000): An inside perspective of the true shrikes - a revive of the helminthofauna, Ring 22, 1: 185 - 204. Retrieved from: http://www.wbwp-fund.eu/ring/

ISKOVA, N. I. (1979): [Data on trematode fauna of Turdidae of the Ukraine]. Vestnik Zoologii (3): 25 - 32

Iskova, N. I., Sharpilo, V. P., SHARPILO, L. D., TKACH, V. V. (1995): [Catalogue of helminths of vertebrates in the Ukraine. Trematodes of terrestrial vertebrates], Kiev, 93 pp. (In Russian)

ISOMursu, M. O., RÄTTI, P. H., HollméN, T. (2006): Sex and age influence intestinal parasite burden in three boreal grouse species. J. Avian Biol., 37: 516 - 522. DOI: 10.1111/j.2006.0908-8857.03838.x

DE Jong, Y. S. D. M. (Eds). (2013): Fauna Europaea version 2.6. Web Service available online at http://www.faunaeur.org

Jones, A, Bray, R. A., Gibson, D. I. (Eds) (2005): Keys to the Trematoda Volume 2, London: CABI Publishing \& Natural History Museum, 745 pp.

Korodi-GaL, J. (1967): Beiträge zur Kenntins der Brutbiologie der Amsel (Turdus merula L.) und zur Ernährungsdynamik ihrer Jungen. Zoologische Abhandlungen. Staatliches Museum für Tierkunde in Dresden, 29: $25-53$

MACHAlSKA, J. (1974): Psilotornus confertus sp. n. (Trematoda, Psilostomatidae), a parasite of birds of the genus Turdus L., Acta Parasitol. Pol., 22 (15): 171 - 178 MACHALSKA, J. (1978) The morphological variability and taxonomic status of Urogonimus macrostomus (Rudolphi, 1803) (Trematoda, Leucochloridiidae), Acta Parasitol. Pol., 26(1): 1 - 9

MACHALSKA, J. (1980a): Helmint fauna of birds of the genus Turdus examined during their spring and autumn migration. I. Digenea, Acta Parasitol. Pol., 27(18): 153 172

MACHALSKA, J. (1980b): Cyclocoelum polonicum sp. n. (Trematoda, Cyclocoelidae) from the thrushes Turdus philomelos Br. and T. merula L., Acta Parasitol. Pol., 26(14): $129-136$

MACHALSKA, J. (1981): Helminth fauna of birds of the genus Turdus examined during their spring and autumn migration. II. Acanthocephalans, Acta Parasitol. Pol., 28(17): $171-177$

MachalsKa, J., OKUlewiCZ, A. (1984): Helminth fauna of birds of the genus Turdus L. examined during their spring and autumn migration. III. Nematoda, Acta Parasitol. Pol., 29(37): 343 - 351

MAgURRAn, A. E. (2004): Measuring biological diversity. Oxford: Blackwell, 256 pp.

MARgolis, D. J., CONE, D. K. (1997): Food webs: a plea for parasites. Trends Ecol. Evol., 12: 320 - 325. DOI: 10.1016/s0169-5347(97)89919-3
MisOF, K. (2005): Eurasian Blackbirds (Turdus merula) and their gastrointestinal parasites. A role for parasites in lifehistory decisions? Dissertation zur Erlangung des Doktorgrades der Mathematisch-Naturwissenschaftlichen Fakultat der Rheinischen Friedrich-Wilhelms-Universitat Bonn. Retrieved from: http://hss.ulb.uni-bonn.de/2005/0661/0661.htm NieWIAdOMSKA, K., PoJMAŃSKA, T. (2004): [Parasitic organisms: why their occurrence should be monitored]. Biuletyn Monitoringu Przyrody 1/2004 (5): 43 - 51 (In Polish)

OKULEWICZ, A. (1979a): [Nematoda of blackbird (Turdus merula L.) and mavis (Turdus philomelos Br.) from the Wrocław region. I. Faunistic studies]. Wiad. Parazytol., 25(3): 468 - 486. PMID:524890. (In Polish)

OKULEWICZ, A. (1979b): [Nematoda of blackbird (Turdus merula L.) and mavis (Turdus philomelos Br.) from the Wroclaw district. II. Ecological study]. Wiad. Parazytol., 25(4): 468 - 486. PMID 516737. (In Polish)

OKULEWICZ, A. (1979c): [Physaloptera (Pseudophysaloptera) sorcina (Baylis, 1934) in a blackbird (Turdus merula L.)] Wiad. Parazytol., 25(4): 487 - 489. PMID 574688. (In Polish)

OKULEWICZ, A. (1981): [Ornithofilaria mavis (Leiper, 1909) Gönnert, 1937 in blackbird (Turdus merula L.) in Poland]. Wiad. Parazytol., 27(4/5): 669 - 671. PMID: 7336749. (In Polish)

OKULEwICZ, A. (1997): Catalogus faunae parasiticae poloniae. Parasiti avium. Nematoda. In: Katalog Fauny Pasozytniczej Polski. Cz. 4. Z. 2B. Warszawa: Polskie Towarzystwo Parazytologiczne, pp. 1 - 147. (in Polish)

OKULEWICZ, A., OKULEWICZ, J., Hildebrand, J., ZAleśNY, G. (2007): New data on straggled eyeworm Oxyspirura chabaudi (Baruš, 1965) (Nematoda, Thelaziidae) in Europe. Acta Parasitol., 52(3): 292 - 294. DOI: 10.2478/ s11686-007-0039-7

Okulewicz, A., Okulewicz, J., Sitko, J., Wesolowska, M. (2010): New records of digenean flukes (Trematoda) in birds in Poland, Wiad Parazytol 56(1): 67 - 70

OKULEwiCZ, A., SitKo, J. (2012): Parasitic helminthes - a probable cause of death of birds, Helminthologia, 49 (4): 241 - 246. DOI: 10.2478/s11687-012-0045-7

OKULEWICZ, J. (1982): [Trematoda of birds of Lower Silesia. I. Euamphimerus pancreaticus Baer, 1960 (Opisthorchiidae, Trematoda) - new parasite of the blackbird (Turdus merula L.) in Poland and remarks with regard to the systematic position of other species of the genus Euamphimerus Yamaguti, 1941]. Wiad Parazytol 28(3/4): 465 - 475. PMID: 7183016 (In Polish)

OKUlewiCZ, J. (1991): Ptilolepis philomelae sp. n. (Cyclophyllidea, Dilepididae) - a new parasite of Turdus philomelos Brem. Acta Parasitol. Pol., 36: 75 - 78

OKULEWICZ, J. (1992): [Trematodes of birds from Lower Silesia III. Urotocus rossitensis (Mehling, 1898) - new for Poland species of trematode parasitism in passeriform birds]. Wiad. Parazytol., 37: 471 - 480. PMID:1844788. (In Polish) 
OKulEwiCZ, J. (1993): [Bird trematodes of lower Silesia. IV. Specimens from the genus Mosesia (Pleurogenidae, Trematoda) - new element of parasitic-fauna passeriform birds from lower Silesia]. Wiad. Parazytol., 39: 39 - 47. PMID:8346659. (In Polish)

OKULEWICZ, J., WeSOŁOWSKA, M. (2000): The occurrence of Dilepis undula (Schrank, 1788) (Cestoda) in Turdus merula and Turdus philomelos. Acta Parasitol., 45(3): 162 OKULEWICZ, J, WESOŁOWSKA, M. (2003): Rediscovery of Leyogonimus postgonoporus (Neiland, 1951) (Trematoda, Stomylotrematidae) in Central Europe. Acta Parasitol., 48: $233-236$

POJMAŃSKA, T. (1969): Leucochloridium perturbatum sp. n. (Trematoda, Brachylaimidae), morphology, individual variability and life cycle. Acta Parasitol., 16: 153 - 178 PojMańsKa, T., NiEWiadomska, K., OKUlewicz, A. (2007): Parasitic helminths of Poland. Species, hosts, uncharted territories. Warszawa: Polskie Towarzystwo Parazytologiczne, 360 pp. (In Polish)

Poulin, R. (1996): Sexual inequalities in helminth infections: a cost of being a male? American Naturalist 147: 287 - 295. DOI: 10.1086/285851

Roberts, M. L., BuchanAN, K. L., Evans, M. R. (2004): Testing the immunocompetence handicap hypothesis: a review of the evidence. Anim. Behav. 68: $227-239$

Robinson, S. A., Forbes, M. R., Hebert, C. E., MCLAughlin, J. D. (2008): Male-biased parasitism by common helminthes is not explained by sex differences in body size or spleen mass of breeding cormorants Phalacrocorax auritus. J. Avian Biol., 39: 272 - 276. DOI: 10.1111/j.0908-8857.2008.04340.x

RUTKOWSKA, M. A. (1973): Studies on the helminth fauna of the Corvidae in Poland. Acta Parasitol. Pol., 21: 183 - 237

RYŠAVÝ, B. (1955): [Fluke (Trematoda) in Turdus merula L. in surroundings of Prague]. Zool. entomol. listy, 4: 271 274 (In Czech)

RYŠAVÝ, B. (1958): [On some interesting trematodes of synanthropic birds in the surroundings of Prague]. Živa 6: 108 - 109 (In Czech)

RYŠAVÝ, B., BARUŠ, V. (1964): Saissondynamik der Invasion von Dilepis undula Schrank, 1788 (Cestoidea: Dilepididae) und Porrocaecum ensicaudatum Zeder, 1800 (Nematoda, Anisakidae) in Amseln (Turdus merula L.) in der Tschechoslowakei. Čsl. Parazitol., 11: 225 - 232

RZĄD, I., SiTKO, J., WYSOCKI, D., STĘPNIEWSKI, K. (2011): Digenean trematodes from six species of birds (Passeriformes, Piciformes and Strigiformes) from north-western Poland. Wiad. Parazytol., 57: 271 - 276

SALAMATIN R. V. (2000): [Cyclophillidean cestodes of the family Dilepididae from terrestrial birds in Ukraine].
Summary of PhD thesis. Kyiv, Ukraine: I. I. Schmalhausen Institute of Zoology, 20 pp. (In Ukrainian)

SAlAmATIN, R., RZĄD, I., WYSOCKI, D. (2007): Spasspasskya dubinini and Monopylidium caenodex (Cestoda: Dilepididae): first record in Poland. Wiad. Parazytol., 53 (suppl.): 33

Salamatin, R.V., Karczewska, A., Wesolowska, M., RZĄD, I. (2010): Cestodes of thrushes (Turdidae): new data for Poland. In: Hodová I., Koubková, B. (Eds) $18^{\text {th }} \mathrm{Hel}$ minthological Days 2010, Brno: Masaryk University, p. 44 SCHALK, G., ForBES, M. R. (1997): Male biases in parasitism of mammals: effects of study type, host age, and parasite taxon. Oikos, 78: $67-74$

SCHMIDT, G. D. (1975): Sphaerirostris wertheimae sp. n., and other Acanthocephala from vertebrates of Israel. $J$ Parasitol 61: 298 - 300

SitKo, J., OKUlEwiCZ. J., NoGA, L. (2000): Variability and systematic status of Lutztrema attenuatum (Dujardin, 1845) comb. n. (Trematoda, Dicrocoeliidae) parasitizing passerine birds. Helminthologia, 37: $79-111$

SitKo, J., FAltÝnKOvÁ, A., Scholz, T. (2006): Checklist of the Trematodes (Digenea) of Birds of the Czech and Slovak Republics, Praha, Academia, 112 pp.

SITKO, J., ZALEŚNY, G. (2014): The effect of urbanization on helminth communities in the Eurasian blackbird (Turdus merula L.) from the eastern part of the Czech Republic, J. Helminthol., 88(1):97 - 104. DOI: 10.1017/S0022149X12000818

SulgostowskA, T. (1997): Catalogus faunae parasiticae poloniae. Parasiti avium. Acanthocephala. In: Katalog Fauny Pasozytniczej Polski. Cz. 4. Z. 1. Warszawa: Polskie Towarzystwo Parazytologiczne, pp. 1 - 29. (In Polish) SulgostowskA, T., CZAPlińsKA, D. (1987): Catalogus faunae parasiticae poloniae. Parasiti avium. Protozoa et Trematoda. In: Katalog Fauny Pasozytniczej Polski. Cz. 4. Z. 1. Warszawa: Polskie Towarzystwo Parazytologiczne, pp. 1 - 208. (In Polish)

WYSOCKI, D. (2002): Biometrical analysis of an urban population of the blackbird (Turdus merula) in Szczecin (NW Poland). Ring, 24: $69-76$

ZUK, M., MCKEAN, K. A. (1996): Sex differences in parasite infections: patterns and processes. Int. J. Parasitol., 26: $1009-1024$

ZYSKOWSKI, D., WYSOCKI, D. (2011): Wintering strategies in urban blackbirds Turdus merula population in Szczecin during years 1997 - 2011. In: INDYKIEWICZ P, JERZAK L, BOHNER J, KAVANAGH, B. (Eds). Urban fauna: studies of animal biology, ecology and conservation in european cities, Bydgoszcz, pp. 487 - 494 